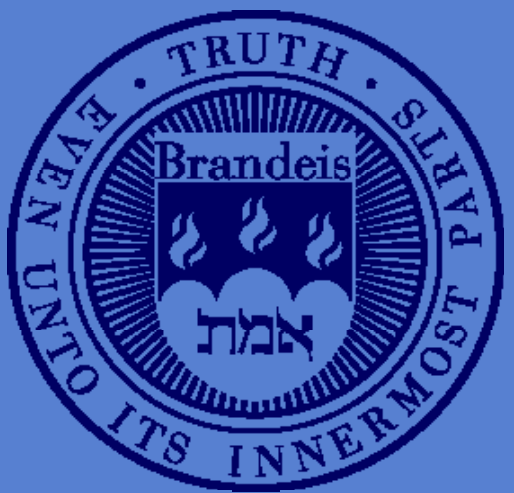

\title{
Board Overlaps in Mutual Fund Families
}

Elif Sisli-Ciamarra, Economics Department, Brandeis University

Abigail Hornstein, Wesleyan University

\section{Working Paper Series}




\title{
Board Overlaps in Mutual Fund Families
}

\author{
Abigail Hornstein $^{\mathrm{a}}$, Elif Sisli Ciamarra ${ }^{\mathrm{b}}$ * \\ ${ }^{a}$ Wesleyan University, 238 Church Street, Middletown, CT 06459, Email: \\ ahornstein@wesleyan.edu \\ ${ }^{\mathrm{b}}$ Brandeis University, 415 South Street, MS 032, Waltham, MA 02478, U.S.A. Tel: +1 \\ (781) 736-8544. E-mail: esisli@brandeis.edu
}

\begin{abstract}
We examine a unique characteristic of mutual fund governance: a common set of directors serving simultaneously on the boards of multiple funds within a fund family. At first glance, this governance structure appears to benefit investors because it is associated with higher fund returns and better fund manager quality. However, funds with higher degrees of board overlap also charge higher marketing and distribution fees, which have been criticized as being the least transparent cost component for mutual fund investors. Board overlaps are also associated with detrimental unobserved actions by fund managers: window dressing and strategic performance transfer between funds occur more often in mutual fund families with greater degrees of director overlap. We conclude that director oversight of multiple funds is a mixed blessing.
\end{abstract}

JEL classification: G23, G11, G34

Keywords: mutual funds, mutual fund families, board of directors

\footnotetext{
${ }^{*}$ We thank Vikas Agarwal, Daniel Bergstersser, Jose-Miguel Gaspar, Kathryn Graddy, Jens Hilscher, Aldo Musacchio, Debarshi Nandy, Laura Starks, Lawrence White, Zafer Yuksel, Shan Zhao, and seminar participants at the Brandeis International Business School, Hunter College, New York University's Stern School of Business, the 2015 Boston Area Finance Symposium, and the International Conference of the French Finance Association (2015). Hornstein thanks the Mellon Foundation for financial support. Part of this work was completed while Hornstein was a visiting scholar at New York University's Stern School of Business. We also gratefully thank Deniz Civril, Yubing Cui, Eugene Kisselev, Geofrey Lordi, Brian Lau, Alex Moris, Jimmy Ong, Richa Sahay and Na Wang for excellent research assistance. All errors are our own.
} 


\section{Board Overlaps in Mutual Fund Families}

\section{Introduction}

The majority of mutual funds in the U.S. are set up by mutual fund sponsors (such as Fidelity, Vanguard, and Merrill Lynch), which manage and sell multiple individual funds. When a fund is initially incepted, its board of directors is appointed by the fund sponsor that launches the fund. The board of a newly launched fund is often composed of the same directors that serve the rest of the funds in the fund family. Therefore, a dominant board structure in the U.S. mutual fund industry has emerged: a common set of directors serving simultaneously on the boards of multiple funds within the family. For example, Fidelity's bond, money market, and asset allocation funds are overseen by one board of directors and another board oversees its equity and high income funds. Fidelity is not an exception in the mutual fund industry. The Investment Company Institute (ICI) reports that the majority

of the mutual funds in the U.S. possess a "unitary" board structure, where a single board governs all of the funds operating under the fund family's umbrella. The rest of the funds follow a "cluster" board model, where a few boards oversee a few clusters of multiple funds (e.g., equity funds and fixed income funds) within the family, as is true for Fidelity (ICI, $2009 ;$ ICI, 2012).

The main rationale for the director oversight of multiple funds is the presumption that it decreases the cost of operating the funds due to the economies of scale it generates. For example, the Independent Directors Council Task Force Report on Director Oversight of 
Multiple Funds (May 2005) ${ }^{1}$ concludes that "mutual funds within a fund family share the same investment adviser and other key service providers and, as a result, significant efficiencies are realized when a single or limited number of boards oversee all of the funds." It is also frequently contended that such overlapping boards are able to drive down the funds' costs due to the increase in their bargaining power when negotiating with the service providers for multiple funds (Kong and Tang, 2008). Both the economies of scale and bargaining power arguments imply lower costs for mutual fund investors, providing justification for overlapping board structures within fund families. ${ }^{2}$

However, the director oversight of multiple funds is not free of criticism. A significant concern is that director overlaps may exacerbate the conflicts between mutual fund investors and the fund management company. Among the main responsibilities of a mutual fund board are to monitor the mutual fund company and negotiate their fees. Under SEC regulations, each fund that operates under the umbrella of a mutual fund management company is a separate legal entity with its own set of investors. Since each fund may have different objectives and dissimilar investors, it may be difficult for a single board to serve simultaneously and effectively the interests of the investors of each fund within a family. A single set of directors overseeing multiple funds may make it easier for mutual fund families to favor those funds that are more likely to increase overall family profits (Chevalier and Ellison, 1999; Nanda et al., 2004), for example by strategically subsidizing funds with high-fee structures (Gaspar et al., 2006). In fact, the Securities and Exchange Commission (SEC) explicitly mandates

\footnotetext{
${ }^{1}$ https://www.idc.org/pdf/ppr_idc_multiple_funds.pdf

${ }^{2}$ We use "director oversight of multiple funds," "director overlap," and "board overlap" interchangeably in the paper.
} 
that that mutual fund boards must monitor to guard against cross-subsidization. ${ }^{3}$ This agency problem is exacerbated by the fact that the mutual fund directors, unlike corporate directors, do not stand for annual reelection by the funds' investors but are reappointed and compensated by the fund management companies. As Tufano and Sevick (1997) point out, "Lawsuits have alleged that well-paid independent directors can become rubber stamps, approving higher fees for the sponsor and thereby failing to exercise their fiduciary duty."

Another significant concern for overlapping boards is that busy boards may not be effective monitors (Fich and Shivdasani, 2006). Fich and Shivdasani (2006) define busy corporate directors as those who serve simultaneously on three or more corporate boards. Mutual fund directors are a lot busier, frequently serving on a far larger number of boards. Despite commonalities across different funds, the workloads of mutual fund directors can be substantial because each fund still has its own lengthy prospectus, regulatory filings and compliance issues to review. John Bogle, the founder and retired CEO of Vanguard has stated that "The required reading underscores the challenge. Mutual fund directors are either not being paid nearly enough for what they should be doing - or far too much for what they actually do." ${ }^{4}$ In keeping with such concerns, Ferris and Yan (2007) present evidence that director busyness, proxied by the number of funds overseen by the individual director, is associated with higher mutual fund fees.

Given that the overlapping board structure may offer both benefits and costs, it is unclear if it is ultimately in the best interest of mutual fund investors for boards to advise and

\footnotetext{
${ }^{3}$ The SEC rules can be viewed at https://www.sec.gov/rules/final/finend.txt.

4 "Is Your Fund's Board Watching Out For You?," available at http://online.wsj.com/articles/SB10001424052702303753904577450243418998540.
} 
monitor multiple funds within a family simultaneously. While director overlaps in mutual fund families have attracted attention of the media as well as the legal experts, ${ }^{5}$ the academic research on the topic remains limited. In this paper, we fill this gap in the mutual fund governance literature by performing a comprehensive analysis of the impact of director oversight of multiple mutual funds. We analyze the relationship between director overlap and mutual fund characteristics such as fees and returns, as well as the impact of board overlap on hidden actions of fund managers such as window dressing and cross-fund subsidization.

We construct a unique dataset on mutual fund boards, in which, for every fund in the sample we identify its ultimate fund sponsor and develop measures for the extent of director overlap with the rest of the funds that are sponsored by the same fund management company. Our sample consists of 3,948 domestic U.S. equity funds that contain 11,598 mutual fundclasses, which belong to 328 distinct fund families. The mean (median) fund family in our sample operates 169 (123) fund classes. We perform our analyses at the fund-class level as in Bergstresser et al. (2009) because one of the main duties of fund boards is to negotiate the fee structure with the key service providers and fees differ between fund classes. In addition, the SEC clearly states that a fund's board has fiduciary duties for investors at the fund-class level.

59 percent of the funds in our sample of equity funds belong to families that have a unitary board structure and the rest of the fund families exhibit a considerable overlap of directors serving on the boards of their individual funds. To quantify the variation in

\footnotetext{
${ }^{5}$ For example, see "On Board, at a Mutual Fund," Wall Street Journal, September 3, 2014, available at http://www.wsj.com/articles/on-board-at-a-mutual-fund-1409757187.
} 
director overlap among fund families that do not have perfect board overlap we develop two additional measures. First, we calculate the percentage of funds in a family that each individual director oversees and obtain the average of this ratio across all directors in each individual fund. For example, the Fidelity Blue Chip Value Fund has a director overlap ratio of 0.95 , meaning that on average, a director of this fund oversees 95 percent of all funds within the Fidelity family. Second, recognizing that some funds may be more important to a particular fund family because they manage larger assets, we also calculate the assetweighted director overlap ratio. Continuing with our example, the asset-weighted director overlap ratio for Fidelity Blue Chip Value Fund is 0.98, meaning that on average, a director of this fund oversees 98 percent of the fund family's assets.

We start our analysis by investigating the relationship between director oversight of multiple funds and mutual fund fees. If the overlapping board structure offers economies of scale and bargaining advantages with the fund service providers resulting in cost savings, and if these cost savings are passed on to the fund investors, then there should be a negative relationship between measures of director overlap and fund fees. However, our findings do not support this view: Expense ratios, management fees and total fees do not differ between funds with different magnitudes of director overlap. Moreover, we find that $12 \mathrm{~b}-1$ fees are significantly higher for funds with greater degrees of director overlap. 12b-1 fees include fees paid for marketing and selling fund shares, such as compensating brokers and others who sell fund shares, and paying for advertising, the printing and mailing of prospectuses to new 
investors, and the printing and mailing of sales literature ${ }^{6}$. These fees have been criticized as being the least transparent cost component for mutual fund investors (e.g., Bergstresser et al., 2009), and the SEC asked whether they result in "investors overpaying for services or paying for distribution services that they may not even know they are supposed to be getting." 7

How a mutual fund is governed can affect the returns earned by investors in the funds. Mutual funds that have unmitigated conflicts between managers and investors may have lower fund performance (Mahoney, 2004; Ding and Wermers, 2012) while funds with good corporate governance may enjoy higher returns (Cremers et al., 2009). Thus, we next investigate the relationship between board overlap and fund returns and find mixed results. Gross returns are positively associated with director overlap, whereas evidence is mixed for net returns (gross returns minus fees). We find no significant relationship between fund alphas and board structure.

Among the main duties of mutual fund boards are to hire the fund managers and monitor their performance. Therefore, higher gross returns earned by funds with greater director overlap may be a result of these funds attracting and retaining better quality portfolio managers and would be a result of good corporate governance. We calculate the "return gap" (Kacperczyk et al., 2008) to gain insight into whether the overlapping boards are able to help the funds employ better quality managers. Return gap is the difference between a fund's actual performance from the performance of the fund's previously disclosed portfolio

\footnotetext{
${ }^{6}$ A detailed description of these fees can be found at http://www.sec.gov/answers/mffees.htm.

7 On July 21, 2010, the SEC proposed "Measures to Improve Regulation of Fund Distribution Fees and Provide Better Disclosure for Investors." See http://www.sec.gov/news/press/2010/2010-126.htm
} 
and has been used as a proxy for managerial skill in the literature (e.g., Agarwal et al., 2014). Our results indicate a significant and positive relationship between the return gap and director overlap, and hence support the claim that overlapping boards help hire and retain more skilled managers.

Our results so far are mostly in favor of the overlapping board structure: such boards are associated with higher returns and better managerial skill. Next, we turn to analyzing the unobserved actions of fund families and fund managers that are potentially harmful to funds' investors. An example of such unobserved actions is that the mutual fund families may coordinate the actions of individual funds in order to maximize profits at the family level (Nanda et al., 2004; Guedj and Papastaikoudi, 2004; Gaspar et al., 2006; Eisele et al., 2013). Such coordinated strategies may involve a strategic performance transfer from one fund to another, and therefore represent an important agency problem that needs to be monitored by mutual fund boards. For example, Gaspar et al. (2006) show that mutual fund families strategically transfer performance across member funds to favor funds that generate the most fees. We follow the empirical strategy of Gaspar et al. (2006) and present evidence that strategic performance transfer occurs more often in families with higher board overlap.

Another unobserved action of mutual funds is window dressing, whereby portfolio managers tilt portfolio holdings towards winner stocks and away from loser stocks right before the portfolio disclosure dates in order to give investors a false impression of stock picking ability (Ritter and Chopra, 1989; Lakonishok et al., 1991; Morey and O’Neal 2006; Solomon et al., 2014; Agarwal et al., 2014). Window dressing is costly for the fund investors as they 
incur transaction costs without promising returns and need to be monitored by mutual fund boards. We investigate the occurrence of window dressing using the "backward holdings return gap," a measure developed by Agarwal et al. (2014). We find a significant and positive relationship between director overlap and window dressing.

To summarize, these results indicate that an overlapping board structure is a mixed blessing. On the plus side, it is associated with somewhat higher fund returns and better fund manager quality. On the minus side, when director overlap is higher we observe that the 12b-1 fees are higher and also that there is a greater prevalence of both strategic performance transfer from high-fee to low-fee funds and window dressing.

Our research contributes to the literature on mutual fund governance. The focus in this literature has been on the board size (Khorana et al., 2007; Meschke, 2007), the independence of the board of directors (Khorana et al., 2007; Ferris and Yan, 2007; Meschke, 2007; Tufano and Sevick, 1997; Del Guercio et al., 2003; Ding and Wermers, 2012; Kuhnen, 2009), director ownership in funds (Chen et al., 2008; Cremers et al., 2009), and mutual fund boards' connections with the corporations (Cohen et al., 2007). We are aware of only two earlier studies that explicitly examine the consequences of board overlap in mutual fund families: Kong and Tang (2008) and Tufano and Sevick (1997). Kong and Tang (2008) study the impact of unitary boards (i.e., complete board overlap), and they present evidence for a negative relationship between fund expenses and unitary boards, and no relationship between fund performance and unitary boards. Since their measure of board overlap does not vary among funds in a fund family, they are not able to control for fund family heterogeneity 
by including family fixed effects. Tufano and Sevick (1997) is more similar to our study in that they develop several measures that capture incomplete overlap between boards within a single family. However, the focus of their study is solely on fund fees and they find that overlapping boards are associated with lower fees - a result that is contrary to our findings. The difference might be a result of our sample spanning more than a single year, which allows us to control for family characteristics such the size of each fund family. In addition, we study the consequences of board overlaps with an extensive set of fund outcomes that signal board effectiveness (fees, returns, managerial skill, window dressing, performance transfer) and thus present the most comprehensive analysis of the director oversight of multiple funds in the literature.

\section{Data}

\subsection{SAMPLE FORMATION}

The sample consists of U.S. equity mutual funds with Lipper asset codes marked as "EQ" in the Center for Research in Securities Prices (CRSP) Mutual Fund Database in 2007. This database covers U.S. open-end mutual funds and provides information on fund characteristics including returns, total net assets, fees, and investment objectives. Since our focus is actively managed mutual funds, passively managed funds such as index funds (and ETFs) are excluded from the sample. For each individual fund, we manually identify its ultimate 
fund family. ${ }^{8}$

The final dataset contains information on 3,948 funds that have 11,598 individual fundclasses and belong to 328 mutual fund families. We collect the board data at the fund-class level because the SEC explicitly mandates that the mutual fund directors have fiduciary responsibilities for shareholders at the fund-class level, not the fund itself. ${ }^{9}$ While the SEC mandate would be consistent with the fund family appointing different boards for each fund class, it turns out that all funds in our sample have the same board representing all classes. Since our unit of analysis is a fund-class, from here on, we use "fund" and "fund-class" interchangeably.

\subsection{DATA ON MUTUAL FUND DIRECTORS}

We use publicly available certified shareholder reports (N_CRS) and prospectuses (485BPOS) to build a unique database of directors for each fund-class in 2007. These reports are available at the SEC Edgar database. For each individual mutual fund we record the names of directors, their tenures on the board, whether the director serves as the CEO of the fund, their independence status, the size of the board, and whether the chairman of the board is independent of the fund management company. We consider a director to be independent if the individual has not had a significant business relationship with the fund's adviser, dis-

\footnotetext{
${ }^{8}$ Kuhnen (2009) provides detailed description of the fund family structure, and we follow her methodology in identifying the ultimate fund families.

${ }^{9}$ The SEC has stated that "Consistent with its oversight of the class system and its independent fiduciary obligations to each class, the board must monitor the use of waivers or reimbursements to guard against cross-subsidization between classes. In making its findings, the board should focus, among other things, on the relationship among the classes and examine potential conflicts of interest among classes regarding the allocation of fees, services, waivers and reimbursements of expenses, and voting rights." The complete text can be accessed at https://www.sec.gov/rules/final/finend.txt.
} 
tributor or affiliates for at least two years, and does not own any stock of the investment advisor or certain related entities.

\subsection{MEASURES OF BOARD OVERLAP IN MUTUAL FUND FAMILIES}

\subsubsection{Unitary Board Indicator}

The extreme case of director overlap, a "unitary board" occurs if all of the individual funds in a fund family are overseen by the same group of directors. Accordingly, we form an indicator variable, "unitary board," which is equal to one when all funds under a mutual fund family have the same board of directors and zero otherwise. This is the measure that is employed in Kong and Tang (2008). 59 percent of the funds in our sample belong to a family that operates under a unitary board structure..$^{10}$ Because all of our regressions incorporate fund family fixed effects, we are not able to use this indicator variable in our main analyses (the value of the indictor variable does not differ for funds within the same family). However, we use this variable to replicate the results in the prior literature (Kong and Tang, 2008), which we present in the Appendix Tables.

Fund families that do not operate under a unitary board structure still exhibit a significant director overlap with common directors serving on boards of multiple fund-classes within the family. This is because director departures from mutual fund boards occur very rarely. ${ }^{11}$ Hence, we develop two additional measures of the director overlap that quantify the

\footnotetext{
10 Since our unit of analysis is fund-class, from here on, we use "fund" and "fund-class" interchangeably

11 Through talking with practitioners in the industry, we have learned that a departure from the unitary
} 
degree of director overlap, which are our main measures. We now describe these measures in detail.

\subsubsection{Count-Based Board Overlap Ratio}

We first count the number of fund-classes in the fund family that each individual director oversees and then scale the sum by the total number of fund-classes in the family. We then obtain the average value across all directors in each mutual fund. Formally, for each fund-class with $\mathrm{N}$ individual directors, we calculate the Board Overlap Ratio as:

$$
\text { Board Overlap Ratio }=\frac{1}{N} \sum_{i=1}^{N} \frac{\text { Number of funds that director-i oversees }}{\text { Total number of funds in the family }}
$$

This variable corresponds to the average percentage of funds in the family that the directors of an individual fund oversee. The mean value of Board Overlap Ratio in our sample is 0.90, meaning that the directors of a fund, on average, serve on $90 \%$ of all boards within their families. We also note that for unitary boards, this measure would be 1.0.

\subsubsection{Asset-Weighted Board Overlap Ratio}

This measure focuses on the monetary value of the assets that are overseen by a director.

We sum up the assets of funds in the fund family that each individual director oversees and

board structure occurs randomly. For example, in some instances a fund may need additional expertise on its board that no other director possesses. Or, it may need someone to assume an additional leadership role (e.g., leading the audit committee) that no current board member is willing to undertake. In other instances, a board member retires and is replaced by another director, but not all funds in the same family stand for election in that particular year. Finally, sometimes, the departure from the unitary board structure occurs as a result of a merger with another fund. 
scale it by the total assets of funds in the family, and then average the measure across all directors in each mutual fund. Formally, for each fund-class with $\mathrm{N}$ individual directors, the Asset Weighted Board Overlap Ratio is calculated as:

Asset-weighted Board Overlap Ratio $=\frac{1}{N} \sum_{i=1}^{N} \frac{\text { Net asset value of funds that director-i oversees }}{\text { Total net asset value of funds in the family }}$

This variable is estimated at the fund-class level and corresponds to the average percentage of assets in the family that the fund's directors oversee. This measure captures the importance of the funds that a director oversees within the fund family, since funds that attract larger assets might be more valuable to the fund families. This measure is similar to Tufano and Sevick (1997)'s measure "board concentration". The mean (median) value of this variable is $90 \%(100 \%)$. Board Overlap Ratio and Asset-weighted Board Overlap Ratio are highly correlated with a correlation coefficient of 0.92 .

\subsubsection{Family Level Measures}

We also form family-level board overlap measures by calculating the average values for Board Overlap Ratio and Asset-weighted Board Overlap Ratio for each fund family. This is accomplished by first calculating the board overlap ratios for individual fund classes in a family and then taking their averages. This family-level board overlap measure has an average value of $90.3 \%$, and is highly correlated with the director overlap ratio. These measures are similar to Tufano and Sevick (1997)'s "sponsor concentration". 
In Appendix 1, we describe how we formed the board overlap measures in more detail using actual examples. We list the variable names, descriptions, and sources in Table 1 and summary statistics for board overlap measures in Table 2, Panel A.

\subsection{FUND CHARACTERISTICS}

We obtain data on fund characteristics from the CRSP Mutual Funds Database for 20072010. In Table 2, Panel B we provide the descriptive statistics for fund characteristics. Fund size is measured as the total net assets under management. We calculate the average monthly total net assets over a calendar year for each fund. Fund family size is the total net assets under management of all funds within a mutual fund complex. Both fund and fund family size capture possible economies (or diseconomies) of scale as fund families share common resources across all funds (e.g., research analysts) and yet the size of a fund may affect its ability to make purchases or sales with minimal impact on market price (Ferris and Yan, 2007). The mean (median) size of a mutual fund is $\$ 462 \mathrm{mn}$ ( $\$ 33 \mathrm{mn}$ ), and the mean (median) size of a fund family is $\$ 93,058 \mathrm{mn}(\$ 21,118 \mathrm{mn})$. In robustness tests we use the number of funds offered by a family in lieu of fund family size. The mean (median) fund family offers 169 (123) fund-classes.

Fund age is estimated as the number of years since a fund was first offered to investors. It is used as a control variable because fund characteristics have been found to vary predictably

over the fund's lifecycle (Tufano and Sevick, 1997; Del Guercio et al., 2003; Ferris and Yan, 2007). The mean (median) fund age is 9.59 years old (8.0 years old). 
We examine separately four types of fees: expense ratios, management fees, $12 \mathrm{~b}-1$ fees, and total fees. Expense ratio is the ratio of total operating expenses to assets under management and includes the management fees, $12 \mathrm{~b}-1$ fees, administrative fees, operating costs, and all other asset-based costs incurred by the fund. We find that the sample mean (median) expense ratio is $135.20 \mathrm{bp}(130 \mathrm{bp})$. Management fees are the fees paid out of fund assets to the fund's investment adviser or its affiliates for managing the fund's portfolio. The sample mean (median) management fee is $49.63 \mathrm{bp}(67.70 \mathrm{bp})$. 12b-1 fees are charged to cover the marketing and distribution costs for a fund. The mean (median) 12b-1 fee is $58.92 \mathrm{bp}(50.00$ bp). Finally, to calculate the total fees faced by a representative investor in a mutual fund class, we add the annualized front and rear-end loads to the expense ratios. Following Sirri and Tufano (1998), we assume that the average investor remains invested in the fund for a period of seven years. The sample mean (median) total fees is $145.72 \mathrm{bp}$ (144bp).

To calculate the net returns, we calculate fund performance in year t by compounding monthly returns from CRSP over the entire year. Net returns are net of all management expenses and 12b-1 fees, as well as front and rear load fees. The sample mean (median) fund generated returns of $297 \mathrm{bp}(1,032 \mathrm{bp})$. Gross returns, which are defined as net returns plus total fees, have a mean (median) value of $443 \mathrm{bp}(1,168 \mathrm{bp})$. In addition, we also estimate funds' alphas. We use the three Fama and French (1992) factors - excess return on the CRSP value-weighted index, difference in returns between a small and large stock portfolio, and difference in returns between a high and low equity to book market portfolio - and the Carhart (1997) momentum factor. Thus, the estimated alpha is a measure of the annual 
abnormal return associated with each mutual fund. The mean (median) estimated value of our four factor alpha is 2.24 basis points $(2.47 \mathrm{bp})$. Finally, we calculate net asset inflows as the annual change in total assets under management. The mean (median) value of net asset inflows is $-\$ 14 \mathrm{mn}(\$ 0 \mathrm{mn})$.

\section{Empirical Methodology}

Throughout our analyses, we relate fund outcomes to board overlap by estimating the following equation:

$$
\text { Fund Outcome }_{i, t}=\alpha_{0}+\alpha_{1} \text { Board Overlap }_{i, 2007}+\alpha_{2} X_{i, t}+\varepsilon_{i, t}
$$

where we regress various fund outcomes (such as fees, returns, unobserved managerial actions) on our board overlap measures and a set of control variables $\left(X_{i, t}\right)$ that has been shown to be correlated with the outcomes in the prior literature. We estimate Equation 1 using weighted least squares (WLS) estimations, where the weights are the share of a fund family in the total number of observations in the sample. We include year, fund family and Lipper investment objective fixed effects in all regressions. Standard errors are clustered to control for possible correlation across observations belonging to the same fund family.

When analyzing policies or institutions such as boards of directors that are centrally organized or overseen by a mutual fund family, it is appropriate to include fixed effects that capture the mutual fund family to mitigate the impact of otherwise unobserved heterogeneity 
in the dataset. We therefore stress the necessity of the inclusion of family fixed effects while estimating Equation 1 and motivate its use following the empirical model offered by Himmelberg et al. (1999). We begin with the assumption that the choice of board structure depends on time-invariant unobservable characteristics of fund i's family, $u_{i}$, as well as observable characteristics of the fund and fund family, $X_{i, t}$. If we assume that there is a linear relationship between the board structure and fund and fund family characteristics we can state:

$$
\text { Board Overlap } \text { i,t }=\alpha+\beta_{1} X_{i, t}+\gamma_{1} u_{i}+e_{i, t}
$$

where $e_{i, t}$ is an i.i.d. error term. Given this board structure, directors choose their actions, $y_{i, t}$, which could relate directly to the degree of director busyness or conflicts as captured in Board Overlap $_{i, t}$, and are potentially also related to the observed and unobserved characteristics of the fund family itself. Again, if there is a linear functional form, the directors' action levels, $y_{i, t}$, can be modeled as:

$$
y_{i, t}=\theta \text { Board Overlap }{ }_{i, t}+\beta_{2} X_{i, t}+\gamma_{2} u_{i}+v_{i, t}
$$

where $v_{i, t}$ is an i.i.d. error term capturing unobservable time-variant fund family characteristics.

Directors' actions can affect multiple fund outcomes such as fees, returns, or unobserved managerial actions such as window dressing. Without loss of generality, we will state our model now in terms of fund fees as that is the first characteristic we analyze later in this 
paper. Fund fees will relate linearly to both the directors' actions and the board structure such that we can state:

$$
\text { Fund } \text { Fees }_{i, t}=\delta y_{i, t}+\beta_{3} X_{i, t}+\gamma_{3} u_{i}+w_{i, t} .
$$

The last equation can be spelled out more completely as:

$$
\text { Fund Fees } i, t=\delta \theta \text { Board Overlap } i, t+\left(\delta \beta_{2}+\beta_{3}\right) X_{i, t}+\left(\delta \gamma_{2}+\gamma_{3}\right) u_{i}+\delta v_{i, t}+w_{i, t},
$$

which can be rewritten more simply as:

$$
\text { Fund } \text { Fees }_{i, t}=\alpha_{0}+\alpha_{1} \text { Board Overlap }_{i, t}+\alpha_{2} X_{i, t}+\varepsilon_{i, t} \text {. }
$$

If the composite fund family error term, $\varepsilon_{i, t}=\left(\delta \gamma_{2}+\gamma_{3}\right) u_{i}+\delta v_{i, t}+w_{i, t}$ is uncorrelated with both board structure (i.e., Board Overlap) and observable fund characteristics, then the coefficient on board structure can be consistently estimated in the analysis of characteristic $\mathrm{X}$. However, as the choice of director actions, $y_{i, t}$, depends on unobserved mutual fund characteristics, $u_{i}$, and is thus correlated with $\varepsilon_{i, t}$, we know that the expected correlation of board structure with the error term from our last equation is unlikely to be zero. Thus, our last equation cannot be estimated using OLS. We therefore include fund family fixed effects in all of our regressions. ${ }^{12}$ We note that Kong and Tang (2008), the study that is closest

\footnotetext{
12 Similarly, recent literature on mutual fund governance (e.g., Gaspar et al., 2006; Kuhnen, 2009; and Chuprinin et al., 2015), also use panel data to allow the introduction of fund family fixed effects.
} 
to ours, do not account for the family fixed effects. In the Appendix Tables, we present the results without fund family fixed effects in order to allow the reader to compare our work to the earlier studies.

A common endogeneity concern in the literature on board of directors is reverse causality (Hermalin and Weisbach, 2003; Adams et al., 2010). As emphasized earlier in footnote 10, boards of directors of mutual funds change rarely, and director departures and replacements are usually precipitated by events such as director retirement, which are not related to fund outcomes. Therefore, we are not very concerned about reverse causality for the director overlap measures.

\section{Results}

\subsection{MUTUAL FUND FEES}

One of the main responsibilities of the board is to negotiate fees. The unitary board structure is thought to be associated with lower fees due to the economies of scale and bargaining power advantages that such structure may provide (ICI, 2009; Kong and Tang, 2008). Thus, we begin by examining the relationship between mutual fund fees charged to investors and the extent of board overlap in mutual fund families by estimating the following equation:

$$
\text { Fund } \text { Fees }_{i, t}=\alpha+\beta \text { Board Overlap }_{i, t}+\sum_{j=1} \gamma_{j} X_{i, t}+\tau_{\text {family }}+\delta_{\text {style }}+\eta_{\text {year }}+\varepsilon_{i, t}
$$


We employ four separate measures for fund fees: expense ratios, management fees, 12-b1 fees, and total fees. The control variables are standard and include the size of the fund, the size of the fund family, age of the fund, age of the fund family, and three other board characteristics that have been show to affect mutual fund fees - board size, board independence, and CEOchairman duality. Fund and family size control for possible economies of scale, and have been shown to be inversely related to fund fees (e.g. Khorana et al., 2008; Kuhnen, 2009). The fund's age is used to capture the lifecycle effect whereby the needs of a fund vary predictably according to its age (Tufano and Sevick, 1997; Del Guercio et al., 2003; Ferris and Yan, 2007). The coefficients on these control variables are as predicted. All our estimations include fund family fixed effects $\left(\tau_{\text {family }}\right)$, fund style fixed effects $\left(\delta_{\text {style }}\right)$, and year fixed effects $\left(\eta_{\text {year }}\right)$.

\subsubsection{Expense Ratios}

Expense ratio for a fund represents the percentage of assets deducted for expenses, which include the management fees, administrative fees, operating costs, 12-b1 fees, and all other asset-based costs incurred by the fund. Controlling for observable characteristics that correlate with how difficult it is to operate the fund (such as its size and investment objective), a higher expense ratio indicates that more of the rents are captured by the management, and less by fund investors (Kuhnen, 2009). We present the results for expense ratios in Table 3, Panel A, columns I-II. Our findings indicate that there is no significant difference between expense ratios of funds with differing magnitudes of director overlap. 


\subsubsection{Management Fees}

One of the largest components of the expense ratio is the management fees, which are the fees paid out of fund assets to the fund's investment adviser or its affiliates for managing the fund's portfolio. By law, the board and fund management companies are required to renegotiate the management fee structure every year. If the overlapping board structure does indeed possess the hypothesized bargaining advantages, then an overlapping board should be associated with lower management fees.

We present the results in columns III and IV of Table 3, Panel A. We obtain evidence that management fees may be lower in the presence of greater board overlap. The coefficient on the director overlap measure is -34.02 and is statistically significant at the 10 percent level. However, this does not hold when the board overlap measure is asset-weighted. This set of results suggests that the potential for economies of scale or bargaining advantages might exist when a fund family has overlapping boards, but that this is less likely to occur as the directors oversee larger assets of the family.

\subsubsection{Marketing and Distribution Costs (12-b1 fees)}

Next, we analyze the relationship between board overlap and $12 \mathrm{~b}-1$ fees. $12 \mathrm{~b}-1$ fees include fees paid for marketing and selling fund shares, such as compensating brokers and others who sell fund shares, and paying for advertising, the printing and mailing of prospectuses to new investors. These fees have been criticized as being the least transparent cost component for mutual fund investors, and the SEC asked whether they result in "investors overpaying for 
services or paying for distribution services that they may not even know they are supposed to be getting." The effectiveness of the marketing costs is not very clear as it has been shown that mutual fund companies offer biased snapshots of their success by selectively advertising their higher performing funds (Koehler and Mercer, 2009). Furthermore, the marketing strategy is usually defined by the fund families, as Gallaher et al. (2015) illustrate that "fund family complexes typically budget their advertising expenditures and enter into advertising contracts on an annual complex-wide basis, making the decisions about when to advertise, and which funds to advertise, later in the fiscal year."

We present the results in Table 3, Panel B, columns I and II. We find that 12b-1 fees are significantly higher when there is higher director overlap- a one standard deviation increase in the director overlap measure would yield an increase in 12 -b1 fees of $10.81 * 0.20$ or $2.16 \mathrm{bps}$. This corresponds to a $3.7 \%$ increase in comparison to the average $12 \mathrm{~b}-1$ fees in our sample (58.92 bps).

\subsubsection{Total Fees}

Last, we investigate the relationship between total fees - expense ratios plus total load fees - and board overlap. Similar to the expense ratio results, we identify no significant relationship between total fees and board structure. These results are reported in Table 3, Panel B, columns III-IV.

To summarize, after controlling both for observed fund and fund family characteristics and fund family fixed effects, we cannot conclude that board overlaps in mutual fund families 
help decrease the fund costs, as has been contended in earlier literature. The negative coefficients on the director overlap measures that were presented in the previous papers (Kong and Tang, 2008; Tufano and Sevick, 1997) are not robust to the inclusion of family fixed effects. In the Appendix tables, we provide the results without incorporating the family fixed effects and generally replicate the results reported in these earlier papers.

\subsection{MUTUAL FUND PERFORMANCE}

Overlapping boards do not seem to negotiate lower fees as we have shown in the previous section, yet they may be using their bargaining power to hire better quality managers. If that is the case, we would expect to see higher returns for funds with greater degrees of director overlap. Therefore, in this section we analyze the relationship between director overlap and fund performance. Specifically, we estimate the following regression equation:

Fund Performance $e_{i, t}=\alpha+\beta$ Board Overlap $i, t+\sum_{j=1} \gamma_{j} X_{i, t}+\tau_{\text {family }}+\delta_{\text {style }}+\eta_{\text {year }}+\varepsilon_{i, t}$.

We use three measures for fund performance: net returns, gross returns and fund alphas. Net and gross returns capture the year-on-year changes in mutual fund value with and without consideration of fees paid by a representative investor. Fund alphas capture fund performance on a risk-adjusted basis and are calculated using Carhart's (1997) 4-factor model. We do not analyze style-adjusted fund returns in either specification as per Gormley and Matsa (2014). All our estimations include fund family fixed effects $\left(\tau_{\text {family }}\right)$, fund style fixed effects 
$\left(\delta_{\text {style }}\right)$, and year fixed effects $\left(\eta_{\text {year }}\right)$.

We present the results in Table 4 . We identify a highly positive and significant relationship between board structure and gross returns. A one standard deviation increase in the director overlap measure (column I) is associated with a 134.2 bps increase in gross returns. Given that the average fund had gross returns of $443 \mathrm{bps}$, this would be a 30 percent increase. Similarly, a one standard deviation increase in the asset-weighted director overlap measure (column II) is associated with a 121.3 bps increase in gross returns. We also obtain a positive and significant relationship between director overlap and net returns when we use the asset-weighted director overlap ratio (column IV). The relationship between fund alphas and board structure is insignificant in all specifications. (columns V and VI).

\subsection{FUND MANAGER ABILITY}

Our results associating board overlap with higher gross and net fund returns indicate that such boards may be more effective in hiring and retaining better managers owing to their bargaining advantages as stressed by the Investment Company Institute (ICI). In this section, we analyze the relationship between board structure and fund manager ability using a measure of managerial skill suggested by Kacperczyk et al. (2008) - KSZ measure henceforth.

The KSZ measure is built on the argument that a fund's disclosed performance would correspond imperfectly with the hypothetical performance that would have been generated if the fund had actually held the publicly disclosed portfolio holdings at the end of the previous 
quarter for the reporting period. This reflects the fact that the fund managers have the ability to trade repeatedly and alter the composition of their portfolios during the reporting period. ${ }^{13}$ Kacperczyk et al. (2008) propose that the "return gap" can be interpreted as a proxy for managerial skill and Agarwal et al. (2014) illustrate with a numerical example why a positive return gap signals managerial skill. For each fund in our sample, we calculate the return gap following Kacperczyk et al. (2008) as follows:

$$
\text { Return Gap }{ }_{i, t}=\text { Actual Return }_{i, t}-\text { Net Holdings Return }_{i, t-1} \text {, }
$$

where Net Holdings Return captures the returns that would have been earned by the fund had it actually held the portfolio disclosed at date t- 1 for the entire quarter. The return gap is thus calculated as the difference between the actual returns and the hypothetical return if the beginning-of-quarter portfolio was held throughout the quarter. A larger return gap implies that a manager's decisions to alter the portfolio since the last disclosure date has resulted in higher performance, and therefore suggests higher managerial skill. Kacperczyk et al. (2008) find that the return gap is persistent and affects fund performance. The mean (median) value of the return gap in our sample is 1.06 basis points $(0.55 \mathrm{bp})$, similar in magnitude to the statistics provided by Agarwal et al. (2014).

After we calculate the return gap, we estimate the following regression equation to relate

${ }^{13}$ Mutual funds disclose the composition of their portfolios on a quarterly basis. 
the managerial skill (i.e., return gap) to director overlap:

$$
\text { Return } \operatorname{Gap}_{i, t}=\alpha+\beta \text { Board Overlap } i, t+\sum_{j=1} \gamma_{j} X_{i, t}+\tau_{\text {family }}+\delta_{\text {style }}+\eta_{\text {year }}+\varepsilon_{i, t} .
$$

We present our findings in Table 5. We find a positive impact of board overlap on the return gap- the coefficients on both director overlap measures are positive and significant at the 1 percent level. The economic magnitude of this result is large: a one standard deviation increase in director overlap would cause an increase in the return gap of $15.09^{*} 0.18$ or 2.716 bps (or, if using the asset-weighted measure of director overlap: $13.77^{*} 0.18$ or $2.4786 \mathrm{bps}$ ). By comparison, the average estimated return gap is 1.06 bps. Together with our results on fund returns, we infer that overlapping boards contribute to recruiting more skilled managers.

\subsection{WINDOW DRESSING}

One of the main duties of fund directors is to monitor the portfolio managers on behalf of the funds' investors in order to reduce managers' ability to engage in actions that are not directly observable by the investors and not necessarily of benefit to them. In this section, we analyze a particular hidden action of fund managers - window dressing. Window dressing involves managers altering fund portfolios by disclosing disproportionately higher (lower) holdings in stocks that have done well (poorly) over a reporting period to mislead investors about their true ability (Agarwal et al., 2014).

Agarwal et al. (2014) develop a proxy for the extent of window dressing - the backward 
holding return gap, which is computed as the "difference between the returns of the quarterend portfolio (and assuming that the manager held this same portfolio at the beginning of the quarter) and the fund's actual quarterly return. The intuition is that a window-dressing manager will tilt portfolio holdings towards winner stocks and away from loser stocks to give investors a false impression of stock selection ability after having observed the winner and loser stocks towards the quarter end. Following Agarwal et al. (2014), we compute the backward holding return gap for each fund in our sample as follows:

Backward Holding Return Gap Gackward Holding Return $_{i, t}$, Bctual Return $_{i, t}$.

The backward holding return is the returns of the quarter-end portfolio, while actual return is the returns reported by the fund for that quarter. The mean (median) value of the window dressing measure in our sample is 25.27 (15.01) basis points, comparable to the sample statistics in Agarwal et al. (2014).

We then estimate the relationship between this window dressing proxy and director overlap with the following regression equation:

Backward Holding Return $\operatorname{Gap}_{i, t}=\alpha+\beta$ Board $\operatorname{Overlap}_{i, t}+\sum_{j=1} \gamma_{j} X_{i, t}+\tau_{\text {family }}+\delta_{\text {style }}+\eta_{\text {year }}+\varepsilon_{i, t}$.

We present the results in Table 6 . We find a positive and significant coefficient on the board overlap variable, implying that the funds with higher director overlap engage in more window dressing when compared to the funds in their families with lower degrees of director overlap. 
A one standard deviation in director overlap would generate an increase in the backward holding return gap of $49.10^{*} 0.18$ or 8.838 bps (or, in the case of the asset-weighted director overlap measure of $34.08^{*} 0.18$ or $\left.6.134 \mathrm{bps}\right)$.

\subsection{BOARD OVERLAP AND STRATEGIC PERFORMANCE TRANSFER IN MUTUAL FUND FAMILIES}

There is considerable evidence that mutual fund families follow strategies to maximize the returns to the family as a whole (Chaudhuri et al., 2012; Guedj and Papastaikoudi, 2004), even if at the expense of certain funds within the family. Gaspar et al. (2006) show that mutual fund families boost the performance of the member funds that are more likely to increase overall family profits. For example, fund families have been shown to improve the performance of high-fee funds at the expense of low fee funds. Such strategic performance transfer has been shown to materialize through the fund family coordinating purchases and sales of investments made by particular funds to boost the performance of high fee funds (cross trading), and also when a fund family allocates hot initial public offering (IPO) stocks differentially to the high fee funds under its umbrella.

In this section we investigate whether such strategic performance transfer occurs more often in funds with higher director overlap. A well-functioning board should be effective in preventing such hidden actions which can redirect value away from the investors of certain

funds in the family. We follow Gaspar et al. (2006) and test whether the observed differences in returns between high-fee funds and low-fee funds in a family systematically exceed 
the difference in returns of their investment styles. Specifically, we estimate the following regression equation:

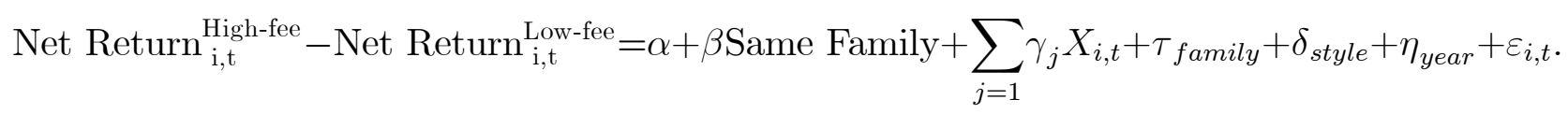

The dependent variable is the difference between the style-adjusted returns of high-fee funds and low-fee funds. A high (low) fee fund is defined as a fund with total fees in the highest (lowest) $25 \%$ of the distribution within the mutual fund family. We note that fees vary widely among the funds included in our dataset. While the mean (median) value of total fees is 145.72 bps ( $144.00 \mathrm{bps})$, the 25 th percentile of the distribution is 99.00 bps and the 75th percentile of the distribution is 195.14 bps. Hence, we are essentially creating pairs of funds where the high fee fund charges fees that are roughly twice as high, or higher, than those of the low fee fund.

Following Gaspar at al. (2006), we construct two sets of return differences between highfee and low-fee funds as follows: In the first set, each high fee fund is matched with all of the low-fee funds belonging to the same family (actual pairs). In the second set, each low-fee fund in every actual pair is replaced by a matching control fund taken from the remaining sample of funds (i.e., funds that belong to a different fund family). To do so, we replace each low-value fund in an actual pair with a low-value fund from another family that has the same investment objective (matched pairs). For each fund we estimate the fund-specific net-of-style return, which is defined as the difference between the fund's monthly return and 
the average return for funds of the same style. We then calculate the difference between the net-of-style returns for the two funds in a pair. The dependent variable is defined as the difference between the net-of-style return of high fund i and the net-of-style return of low fund $j$.

We then stack both sets of pairs together in the same data set to form the dependent variable, Net Return ${ }_{i, t}^{\text {High-fee }}-$ Net Return $n_{i, t}^{\text {Low-fee }}$. "Same Family" is an indicator variable that takes the value one if the low-fee and high-fee fund pairs belong to the same mutual fund family (i.e., actual pairs). The indicator variable takes the value zero if the funds belong to different families (i.e., matched pairs). We include year, style and fund family fixed effects in the regressions. As in Gaspar et al. (2006), control variables consist of size of the funds, the age of the funds, the size of the fund families, and an indicator variable if the high-fee and low-fee funds are of the same style.

Gaspar et al. (2006) show that the coefficient belonging to the same family indicator, $\beta$, is positive and significant and infer from this result that fund families strategically transfer performance from high-fee funds to low-fee funds. Our estimation of the equation yield the same result - for our study sample, we too find a significant and positive coefficient on the "SameFamily" indicator variable (Table 7, column I).

After confirming the occurrence of performance transfer from low-fee funds to high-fee funds within our study sample, we move on to investigate the effects of board overlap on performance transfer by estimating the equation separately for funds that belong to families with high and low degrees of director overlap. To classify the families, we use our family-level 
director overlap measures, which were calculated by averaging the Board Overlap Ratio and Asset-weighted Board Overlap Ratio of each fund within a fund family.

We present the results in Table 7, columns II-V. First, in Columns II and III we form the subsamples using the director overlap ratio and then in Columns IV and V we form the subsamples using the asset-weighted director overlap ratio. We obtain a consistent story: director overlap is strongly associated with greater performance transfer among the high director overlap sample (Columns II and IV) but there is no association among the low director overlap sample (Columns III and V). A one standard deviation in director overlap (asset-weighted director overlap) causes an increase in performance transfer of $47.64^{*} 0.18$ or 8.572 bps $\left(48.44^{*} 0.18\right.$ or 8.7192 bps), which is a roughly $3 \%$ change from the average estimated net returns of a fund in our dataset of 297.3 bps.

\section{Robustness Checks}

\subsection{NUMBER OF FUNDS}

Earlier we proxied for family size using the total value of assets under management in all funds in the family. However, it is possible that the value of assets under management captures only some of the qualities associated with the broad concept of family size. Thus, we now use an alternative proxy of family size - the number of funds in a family. When we re-estimate all regressions, it is now necessary to exclude our asset-based measure of family size, because the value of assets under management within a family is high correlated with 
the number of funds in the family. Our results are qualitatively similar whether we use the asset-based measure of family size or a count-of-funds-based measure of family size.

\subsection{INTERACTIONS OF BOARD OVERLAP MEASURES WITH NUMBER OF FUNDS IN THE FAMILY}

The costs and benefits of director overlap may be more pronounced in bigger families that market a larger number of funds. Therefore, we repeat our analyses by adding the interaction of director overlap and number of funds in a family to our list of explanatory variables. The coefficients on the interaction terms are consistently statistically insignificant and the coefficients on the director overlap measures are qualitatively and quantitatively similar to those shown in all tables.

\subsection{NONLINEARITY}

We also estimated alternative specifications of the regression equation that allow for a nonlinearity in the relation between dependent variables and board overlap. Specifically, we used a quadratic function of board overlap in these models. Our results do not indicate the presence of such non-linearities as all of the quadratic terms are statistically insignificant.

\section{Conclusion}

Our study of overlapping board structures in mutual funds makes two contributions to the literature on governance practices of mutual fund families. First, we develop nuanced 
measures of board overlap to highlight how variation in degrees of board overlap can affect characteristics of mutual funds and estimate these measures for all actively managed equity funds in the CRSP universe. Our count and asset weighted measures of board overlap highlight that even when a fund family does not adopt a unitary board structure, there remains considerable overlap among the boards within a complex.

Second, we perform a comprehensive analysis of the relationship between board overlap and characteristics of funds, both visible and otherwise, in order to identify the different ways that board overlap may matter. We begin by analyzing fund fees as a fund's fee structure is clearly visible to investors and is likely to be considered when making investment allocations. We find that expense ratios, management fees, and total fees are unaffected by the board structure. However, funds charge higher marketing and distribution fees, which are considered to be the least transparent type of cost charged by funds, when they have a higher degree of board overlap. We then look into the impact of board overlap on fund performance, and find that gross returns are significantly higher for funds with greater board overlap. But, when we examine net returns we observe no impact of board overlap. To reconcile these findings we question if board overlap may affect hidden, unobserved characteristics of mutual funds such as strategic performance transfer within a mutual fund family, or managerial behavior as proxied by the forwards or backwards return gaps. Indeed, that is the case. We find that mutual fund families strategically transfer performance to high fee funds within the complex. Moreover, managers are more skilled and window dressing is more common among funds with higher board overlaps. 
To sum up, we show that the overlapping board structure is exceedingly common in the mutual fund industry.However, our results clearly illustrate that investors in funds with overlapping boards do not unambiguously benefit from this structure. Thus, we conclude that the overlapping board structure in the mutual fund industry is a mixed blessing and needs to be reevaluated by both mutual funds themselves and policy makers. 


\section{Appendix 1: Construction of the Board Overlap Measures}

To illustrate how the overlap measures are calculated, we provide three examples. The first example is AARP Fund family, which enter our sample with three equity funds: AARP Conservative Fund, AARP Moderate Fund and AARP Aggressive Fund. The board structure and the assets under management (AUM) as of 2007 are as follows:

\begin{tabular}{llll}
\hline \hline Director & Fund Family & Fund & AUM \\
\hline William L. Boyan & AARP & ARP Conservative Fund & 20.57 \\
Michael F. Holland & AARP & ARP Conservative Fund & 20.57 \\
Rina K. Spence & AARP & ARP Conservative Fund & 20.57 \\
Douglas T. Williams & AARP & ARP Conservative Fund & 20.57 \\
\hline William L. Boyan & AARP & AARP Moderate Fund & 11.25 \\
Michael F. Holland & AARP & AARP Moderate Fund & 11.25 \\
Rina K. Spence & AARP & AARP Moderate Fund & 11.25 \\
Douglas T. Williams & AARP & AARP Moderate Fund & 11.25 \\
\hline William L. Boyan & AARP & AARP Aggressive Fund & 32.71 \\
Michael F. Holland & AARP & AARP Aggressive Fund & 32.71 \\
Rina K. Spence & AARP & AARP Aggressive Fund & 32.71 \\
Douglas T. Williams & AARP & AARP Aggressive Fund & 32.71 \\
\hline
\end{tabular}

For this fund family, there is a complete overlap of the board members across all individual funds. Thus, for each of the funds, the Unitary Board variable would take the value one. "Board Overlap Ratio" and "Asset-weighted Board Overlap Ratio" would also each be equal to 1 for each individual fund.

The second fund family we use as an example is Barrett Fund Family, which enter our sample with Barrett Growth Fund and Barrett Opportunity Fund. The board structure and the assets under management (AUM) as of 2007 are as follows:

\begin{tabular}{lllc}
\hline \hline Director & Fund Family & Fund & AUM \\
\hline \hline Ronald E. Kfoury & Barrett & Barrett Growth Fund & 21.61 \\
Gerard E. Jones & Barrett & Barrett Growth Fund & 21.61 \\
Edward M. Mazze & Barrett & Barrett Growth Fund & 21.61 \\
\hline Irving Brilliant & Barrett & Barrett Opportunity Fund & 152.63 \\
Barry Handel & Barrett & Barrett Opportunity Fund & 152.63 \\
Rosalind A. Kochman & Barrett & Barrett Opportunity Fund & 152.63 \\
William Morris, Jr. & Barrett & Barrett Opportunity Fund & 152.63 \\
Irving Sonnenschein & Barrett & Barrett Opportunity Fund & 152.63 \\
\hline
\end{tabular}


The two funds that operate under the umbrella of the Barrett fund family have completely seperate boards. Thus, the funds under Barrett family have a value of zero for the unitary board dummy, and the board overlap ratios for these funds are also zero.

The third fund family we use as an example is FPA, which enters our dataset with four equity funds. The board structure and the assets under management (AUM) as of 2007 are as follows:

\begin{tabular}{llll}
\hline \hline Director & Fund Family & Fund & AUM \\
\hline \hline Willard H. Altman, Jr & FPA & FPA Capital Fund & 2177.43 \\
Alfred E. Osborne, Jr & FPA & FPA Capital Fund & 2177.43 \\
A. Robert Pisano & FPA & FPA Capital Fund & 2177.43 \\
Patrick B. Purcell & FPA & FPA Capital Fund & 2177.43 \\
Robert L. Rodriguez & FPA & FPA Capital Fund & 2177.43 \\
Lawrence J. Sheehan & FPA & FPA Capital Fund & 2177.43 \\
\hline Rina K. Spence & FPA & FPA Crescent Fund & 1394.45 \\
Douglas T. Williams & FPA & FPA Crescent Fund & 1394.45 \\
William L. Boyan & FPA & FPA Crescent Fund & 1394.45 \\
Michael F. Holland & FPA & FPA Crescent Fund & 1394.45 \\
Rina K. Spence & FPA & FPA Crescent Fund & 1394.45 \\
Douglas T. Williams & FPA & FPA Crescent Fund & 1394.45 \\
\hline Willard H. Altman, J & FPA & FPA Paramount Fund & 467.08 \\
Eric S. Ende & FPA & FPA Paramount Fund & 467.08 \\
A. Robert Pisano & FPA & FPA Paramount Fund & 467.08 \\
John H. Rubel & FPA & FPA Paramount Fund & 467.08 \\
Lawrence J. Sheehan & FPA & FPA Paramount Fund & 467.08 \\
John P. Shelton & FPA & FPA Paramount Fund & 467.08 \\
\hline Willard H. Altman, J & FPA & FPA Perennial Fund & 467.43 \\
Eric S. Ende & FPA & FPA Perennial Fund & 467.43 \\
A. Robert Pisano & FPA & FPA Perennial Fund & 467.43 \\
Lawrence J. Sheehan & FPA & FPA Perennial Fund & 467.43 \\
\hline
\end{tabular}

We will illustrate the calculations for one of the four funds operating under FPA mutual fund family: FPA Capital Fund. This fund has six directors. Mr. Altman is on four boards, Mr. Osborne is on 2 boards, Mr. Pisano is on 4 boards, Mr. Purcell is on 2 boards, Mr. Rodriqguez is on 1 board,and finally Mr. Sheehan is on 4 boards. To calculate our 
count-based overlap measure by equation 1 in the main text:

$$
\begin{aligned}
\text { Board Overlap Ratio }= & \frac{1}{N} \sum_{i=1}^{N} \frac{\text { Number of funds that director-i oversees }}{\text { Total number of funds in the family }} \\
= & \frac{1}{6} \times\left(\frac{4}{4}+\frac{2}{4}+\frac{4}{4}+\frac{2}{4}+\frac{1}{4}+\frac{4}{4}\right) \\
= & 0.71 .
\end{aligned}
$$

To calculate the Asset-weighted Board Overlap ratio, we use equation 2 in the text. The total assets under management (in mn.) for the fund family is:

$$
\$ 2177.43+\$ 1394.45+\$ 467.08+\$ 467.43=\$ 4506.39
$$

Asset-weighted Board Overlap Ratio $=\frac{1}{N} \sum_{i=1}^{N} \frac{\text { Net asset value of funds that director-i oversees }}{\text { Total net asset value of funds in the family }}$

$$
\begin{aligned}
= & \frac{1}{6} \times\left(\frac{\$ 4506.39}{\$ 4506.39}+\frac{\$ 2177.43+\$ 1394.45}{\$ 4506.39}+\frac{\$ 4506.39}{\$ 4506.39}+\right. \\
& \left.\frac{\$ 2177.43+\$ 1394.45}{\$ 4506.39}+\frac{\$ 2177.43}{\$ 4506.39}+\frac{\$ 4506.39}{\$ 4506.39}\right) \\
= & 0.85
\end{aligned}
$$




\section{References}

Adams, R., B. Hermalin, and M. Weisbach (2010). The Role of Boards of Directors in Corporate Governance: A Conceptual Framework and Survey, Journal of Economic Literature, 48(1), 58-107.

Agarwal, V., G. Gay, and L. Ling (2014). Window dressing in mutual funds, Review of Financial Studies, 27(11), 3133-3170.

Bergstresser, D., Chalmers, J. M., and P. Tufano (2009). Assessing the costs and benefits of brokers in the mutual fund industry. Review of Financial Studies, 22(10), 4129-4156.

Carhart M. (1997). On persistence in mutual fund performance, Journal of Finance, $52(1), 57-82$.

Chaudhuri, R., Z. Ivkovich, and C. Trzcinka (2012). Strategic Performance Allocation in Institutional Asset Management Firms: Behold the Power of Stars and Dominant Clients, unpublished working paper, AFA 2013 San Diego Meetings Paper.

Chen, Q., I. Goldstein, and W. Jiang (2008). Directors' ownership in the US mutual fund industry, Journal of Finance, 63(6), 2629-2677.

Chevalier, J., and G. Ellison (1999). Are Some Mutual Fund Managers Better Than Others? Cross-Sectional Patterns in Behavior and Performance, Journal of Finance, $54(3), 875-899$.

Chuprinin, O., M. Massa, and D. Schumacher (2015). Outsourcing in the International Mutual Fund Industry: An Equilibrium View, Journal of Finance, 70, 2275-2308.

Cohen, L., A. Frazzini, and C. Malloy (2007). The small world of investing: Board connections and mutual fund returns, Journal of Political Economy, 116(5), 951-979.

Cremers, M., J. Driessen, P. Maenhout, and D. Weinbaum (2009). Does skin in the game matter? Director incentives and governance in the mutual fund industry, Journal of Financial and Quantitative Analysis, 44(6), 1345-1373.

Del Guercio, D., L. Dann, M. Partch (2003). Governance and boards of directors in closed-end investment companies, Journal of Financial Economics, 69, 111-152.

Ding, B., and R. Wermers (2012). Mutual fund performance and governance structure: The role of portfolio managers and boards of directors, unpublished working paper.

Eisele, A., T. Nefedova, and G. Parise (2013). Predation versus Cooperation in Mutual Fund Families, Swiss Finance Institute Research Paper 13-19. 
Ferris, S., and X. Yan (2007). Do independent directors and chairmen matter? The role of boards of directors in mutual fund governance, Journal of Corporate Finance, 13(2-3), 392-420.

Fich, E., and A. Shivdasani (2006). re busy boards effective monitors?, Journal of Finance, 61(2), 689-724.

Gallaher, S., R. Kaniel, and L. Starks (2015). Advertising and mutual funds: From families to individual funds, CEPR Discussion Paper No. DP10329.

Gaspar, J., M. Massa, and P. Matos (2006). Favoritism in mutual fund families? Evidence on strategic cross-fund subsidization, Journal of Finance, 61(1), 73-104.

Gormley, T., and D. Matsa (2014). Common errors: How to (and not to) control for unobserved heterogeneity, Review of Financial Studies, 27(2), 617-661.

Guedj, I., and J. Papastakaikoudi (2004). Can mutual funds families affect the performance of their funds?, unpublished MIT working paper.

Hermalin, B., and M. Weisbach (2003). Boards of Directors as an Endogenously Determined Institution: A Survey of the Economic Literature, Economic Policy Review, $9(1)$.

Himmelberg, C., R. Hubbard, and D. Palia (1999). Understanding the determinants of managerial ownership and the link between ownership and performance, Journal of Financial Economics, 53(3), 353-384.

Investment Company Institute (ICI) (2009). Overview of fund governance practices 1994-2008, http://www.ici.org/pdf/pub_09_fund_governance.pdf, accessed on January 14, 2012.

Investment Company Institute (ICI) (2012). Frequently asked questions about mutual fund directors, https://www.ici.org/faqs/faq/mfs/ci.faq_fund_gov_idc.idc, accessed July 17, 2012.

Investment Company Institute (ICI) 2012, website, http://www.ici.org, accessed on January 12, 2012.

Kacperczyk, M., C. Sialm, and L. Zheng (2008). Unobserved actions of mutual funds, Review of Financial Studies, 21(6), 2379-2416.

Kacperczyk, M., S. van Nieuwerburgh, and L. Veldkamp (2014). Time-varying fund manager skill, Journal of Finance, 69(4), 1455-1484.

Khorana, A., H. Servaes, and P. Tufano (2008). Mutual fund fees around the world, Review of Financial Studies, 22(3), 1279-1310. 
Khorana, A., P. Tufano, and L. Wedge (2007). Board structure, mergers, and shareholder wealth: A study of the mutual fund industry, Journal of Financial Economics, $85(2), 571-598$.

Koehler, J., and M. Mercer (2009). Selection neglect in mutual fund advertisements, Management Science, 55(7), 1107-1121.

Kong, S., and D. Tang (2008). Unitary boards and mutual fund governance, Journal of Financial Research, 31(3), 193-224.

Kuhnen, C (2009). Business networks, corporate governance, and contracting in the mutual fund industry, Journal of Finance, 64(5), 2185-2220.

Lakonishok, J., A. Shleifer, R. Thaler, and R. Vishny (1991). Window dressing by pension fund managers, American Economic Review, 81, 227-231.

Mahoney, P. (2004). Manager-Investor Conflicts in Mutual Funds, Journal of Economic Perspectives, 18(2), 161-182.

Meschke, F. (2007). An empirical examination of mutual fund boards, SSRN paper 676901 .

Morey, M., and E. O'Neal (2006). Window dressing in bond mutual funds, Journal of Financial Research, 29, 325-347.

Nanda, V., J. Wang, and L. Zheng (2004). Family values and the star phenomenon: Strategies of mutual fund families, Review of Financial Studies, 17(3), 667-698.

Ritter, J., and N. Chopra (1989). Portfolio rebalancing and the turn-of-the-year effect, Journal of Finance, 44, 149-166.

Sirri, E., and P. Tufano (1998). Costly search and mutual fund flows, Journal of Finance, 53(5), 1589-1622.

Solomon, D., E. Soltes, and D. Sosyura (2014). Winners in the spotlight: media coverage of fund holdings as a driver of flows, Journal of Financial Economics, 113, 53-72.

Tufano, P., and M. Sevick (1997). Board structure and fee-setting in the U.S. mutual fund industry, Journal of Financial Economics, 46, 321-355. 
Appendix Table 1. Estimation Results without Family Fixed Effects

Panel A. Expense Ratios and Management Fees

\begin{tabular}{|c|c|c|c|c|c|c|}
\hline & \multicolumn{3}{|c|}{ Expense Ratio } & \multicolumn{3}{|c|}{ Management Fees } \\
\hline & ( 1$)$ & (II) & (III) & (IV) & $(\mathrm{V})$ & $(\mathrm{VI})$ \\
\hline \multirow[t]{2}{*}{ Unitary Board } & -10.67 & & & -2.467 & & \\
\hline & $(8.305)$ & & & (12.13) & & \\
\hline \multirow[t]{2}{*}{ Director Overlap } & & $-26.79 *$ & & & -17.02 & \\
\hline & & $(14.00)$ & & & $(13.90)$ & \\
\hline \multirow[t]{2}{*}{ Asset-weighted Director Overlap } & & & $-23.13^{*}$ & & & -2.652 \\
\hline & & & $(13.24)$ & & & $(13.46)$ \\
\hline \multirow[t]{2}{*}{ Fund Age } & $18.04^{* * *}$ & $17.91 * * *$ & $17.86 * * *$ & $28.03 * * *$ & $27.81 * * *$ & $28.05 * * *$ \\
\hline & $(4.239)$ & $(4.256)$ & $(4.316)$ & (8.661) & $(8.470)$ & $(8.491)$ \\
\hline \multirow[t]{2}{*}{ Fund Size } & $-7.210 * * *$ & $-7.328 * * *$ & $-7.284 * * *$ & $2.056 * *$ & $2.025 * *$ & $2.034 * *$ \\
\hline & $(1.237)$ & $(1.229)$ & $(1.234)$ & $(0.877)$ & $(0.938)$ & $(0.937)$ \\
\hline \multirow[t]{2}{*}{ Family Size } & $-6.465 * * *$ & $-5.867 * * *$ & $-5.808 * * *$ & $-4.685 * * *$ & $-4.824 * *$ & $-4.460 * *$ \\
\hline & $(2.224)$ & $(1.926)$ & $(1.954)$ & $(1.649)$ & $(2.013)$ & $(2.043)$ \\
\hline \multirow[t]{2}{*}{ Board Size } & 19.50 & $22.08^{*}$ & $21.46^{*}$ & 18.81 & 22.03 & 18.58 \\
\hline & $(12.37)$ & $(12.46)$ & $(12.56)$ & $(16.56)$ & (18.79) & $(18.80)$ \\
\hline \multirow[t]{2}{*}{ CEO is the Chairman } & -1.533 & 3.108 & 2.773 & -5.717 & -3.685 & -4.959 \\
\hline & (6.709) & $(6.828)$ & $(6.945)$ & (9.297) & (7.675) & (7.543) \\
\hline \multirow[t]{2}{*}{ Board Independence } & -16.04 & -13.35 & -11.24 & -13.87 & -19.22 & -11.28 \\
\hline & (31.88) & $(28.11)$ & $(27.75)$ & (71.86) & $(57.85)$ & $(58.41)$ \\
\hline \multirow[t]{2}{*}{ Constant } & $184.5^{* * *}$ & $189.0 * * *$ & $184.4^{* * *}$ & 30.39 & 42.56 & 27.70 \\
\hline & $(37.68)$ & $(38.34)$ & $(37.75)$ & (103.7) & (83.97) & $(86.20)$ \\
\hline Year Fixed Effects & Yes & Yes & Yes & Yes & Yes & Yes \\
\hline Style Fixed Effects & Yes & Yes & Yes & Yes & Yes & Yes \\
\hline Family Fixed Effects & No & No & No & No & No & No \\
\hline r2 & 0.314 & 0.315 & 0.314 & 0.180 & 0.181 & 0.180 \\
\hline r2_a & 0.313 & 0.314 & 0.313 & 0.178 & 0.180 & 0.178 \\
\hline $\mathrm{N}$ & 38134 & 38134 & 38134 & 38134 & 38134 & 38134 \\
\hline
\end{tabular}


Appendix Table 1. Estimation Results without Family Fixed Effects

Panel B. 12b-1 Fees and Total Fees

\begin{tabular}{|c|c|c|c|c|c|c|}
\hline & \multicolumn{3}{|c|}{$12 b-1$ Fees } & \multicolumn{3}{|c|}{ Total Fees (Expense Ratio + Loads) } \\
\hline & $(\mathrm{I})$ & (II) & (III) & (IV) & $(\mathrm{V})$ & $(\mathrm{VI})$ \\
\hline \multirow[t]{2}{*}{ Unitary Board } & $-12.18^{* *}$ & & & -13.56 & & \\
\hline & $(6.113)$ & & & (9.480) & & \\
\hline \multirow[t]{2}{*}{ Director Overlap } & & -10.45 & & & $-30.13^{*}$ & \\
\hline & & (9.259) & & & $(15.46)$ & \\
\hline \multirow[t]{2}{*}{ Asset-weighted Director Overlap } & & & -8.268 & & & $-26.23 *$ \\
\hline & & & (8.351) & & & $(14.53)$ \\
\hline \multirow[t]{2}{*}{ Fund Age } & $8.074^{*}$ & $7.867^{*}$ & $7.878^{*}$ & $17.98 * * *$ & $17.88^{* * *}$ & $17.83^{* * *}$ \\
\hline & $(4.383)$ & $(4.367)$ & $(4.364)$ & $(5.410)$ & $(5.449)$ & $(5.524)$ \\
\hline \multirow[t]{2}{*}{ Fund Size } & $-4.170 * * *$ & $-4.297 * * *$ & $-4.287 * * *$ & $-6.347 * * *$ & $-6.497 * * *$ & $-6.446 * * *$ \\
\hline & $(1.140)$ & $(1.216)$ & $(1.216)$ & $(1.589)$ & $(1.578)$ & $(1.580)$ \\
\hline \multirow[t]{2}{*}{ Family Size } & -0.469 & 0.777 & 0.822 & $-7.797^{* * *}$ & $-6.936 * * *$ & $-6.877 * * *$ \\
\hline & $(1.722)$ & $(1.552)$ & $(1.561)$ & $(2.549)$ & $(2.161)$ & $(2.187)$ \\
\hline \multirow[t]{2}{*}{ Board Size } & 3.205 & 1.131 & 0.706 & 22.32 & $24.65^{*}$ & 24.01 \\
\hline & (9.274) & $(11.33)$ & $(11.36)$ & $(14.22)$ & (14.59) & $(14.71)$ \\
\hline \multirow[t]{2}{*}{ CEO is the Chairman } & 1.050 & 3.954 & 3.753 & 1.061 & 6.612 & 6.255 \\
\hline & $(4.925)$ & (5.603) & $(5.648)$ & (7.895) & (8.179) & (8.295) \\
\hline \multirow[t]{2}{*}{ Board Independence } & 7.745 & 24.32 & 25.86 & -7.577 & -2.004 & 0.258 \\
\hline & (27.89) & $(30.96)$ & $(30.85)$ & $(37.28)$ & $(32.93)$ & $(32.46)$ \\
\hline \multirow[t]{2}{*}{ Constant } & $60.76^{* *}$ & $43.96 *$ & $41.17^{*}$ & $195.4^{* * *}$ & $197.1^{* * *}$ & $192.2 * * *$ \\
\hline & $(24.54)$ & (24.59) & $(23.61)$ & $(40.43)$ & (39.64) & $(38.66)$ \\
\hline Year Fixed Effects & Yes & Yes & Yes & Yes & Yes & Yes \\
\hline Style Fixed Effects & Yes & Yes & Yes & Yes & Yes & Yes \\
\hline Family Fixed Effects & No & No & No & No & No & No \\
\hline $\mathrm{r} 2$ & 0.0958 & 0.0788 & 0.0780 & 0.268 & 0.268 & 0.267 \\
\hline r2_a & 0.0935 & 0.0765 & 0.0757 & 0.267 & 0.267 & 0.266 \\
\hline $\mathrm{N}$ & 24036 & 24036 & 24036 & 38134 & 38134 & 38134 \\
\hline
\end{tabular}


Appendix Table 1. Estimation Results without Family Fixed Effects

Panel C. Fund Net Returns and Gross Returns

\begin{tabular}{|c|c|c|c|c|c|c|}
\hline & \multicolumn{3}{|c|}{ Returns Net of Fees } & \multicolumn{3}{|c|}{ Gross Returns } \\
\hline & $(\mathrm{I})$ & (II) & (III) & (IV) & $(\mathrm{V})$ & $(\mathrm{VI})$ \\
\hline \multirow[t]{2}{*}{ Unitary Board } & 7.719 & & & 1.630 & & \\
\hline & $(28.68)$ & & & $(36.78)$ & & \\
\hline \multirow[t]{2}{*}{ Director Overlap (Fund) } & & 70.82 & & & 57.35 & \\
\hline & & (54.11) & & & (64.36) & \\
\hline \multirow[t]{2}{*}{ Asset-weighted Director Overlap (Fund) } & & & 71.97 & & & 65.76 \\
\hline & & & (53.07) & & & $(62.35)$ \\
\hline \multirow[t]{2}{*}{ Fund Age } & $58.96 * * *$ & $59.88 * * *$ & $60.27 * * *$ & $25.91^{* *}$ & $26.86^{* *}$ & $27.31^{* *}$ \\
\hline & $(15.75)$ & $(15.81)$ & $(15.94)$ & $(12.70)$ & $(12.84)$ & $(12.86)$ \\
\hline \multirow[t]{2}{*}{ Fund Size } & $9.215^{* * *}$ & $9.338 * * *$ & $9.210 * * *$ & 0.425 & 0.460 & 0.339 \\
\hline & $(3.021)$ & $(2.989)$ & $(2.991)$ & $(3.221)$ & $(3.367)$ & (3.391) \\
\hline Family Size & (8.695) & $(7.852)$ & $(7.862)$ & (9.812) & (8.356) & (8.328) \\
\hline \multirow[t]{2}{*}{ Board Size } & -1.630 & -16.04 & -17.14 & -1.002 & -14.31 & -17.11 \\
\hline & (62.11) & (65.57) & (65.83) & (74.71) & (79.45) & (79.39) \\
\hline \multirow[t]{2}{*}{ CEO is the Chairman } & $60.23 * *$ & 52.22 & 52.08 & $91.52 * *$ & $86.10 * *$ & $85.38 * *$ \\
\hline & $(28.78)$ & $(32.97)$ & $(32.82)$ & $(37.24)$ & $(40.07)$ & (39.94) \\
\hline \multirow[t]{2}{*}{ Board Independence } & 81.41 & 107.7 & 107.9 & 96.42 & 125.4 & 129.7 \\
\hline & (175.4) & (185.3) & (185.5) & $(200.2)$ & (209.9) & (210.6) \\
\hline \multirow[t]{2}{*}{ Constant } & $1905.2^{* * *}$ & $1849.3^{* * *}$ & $1850.6^{* * *}$ & $2226.5^{* * *}$ & $2171.1^{* * *}$ & $2164.7^{* * *}$ \\
\hline & $(157.4)$ & $(161.8)$ & $(162.6)$ & $(166.9)$ & $(166.1)$ & $(166.0)$ \\
\hline Year Fixed Effects & Yes & Yes & Yes & Yes & Yes & Yes \\
\hline Style Fixed Effects & Yes & Yes & Yes & Yes & Yes & Yes \\
\hline r2_a & 0.862 & 0.862 & 0.862 & 0.866 & 0.866 & 0.866 \\
\hline $\mathrm{N}$ & 39417 & 39417 & 39417 & 38121 & 38121 & 38121 \\
\hline
\end{tabular}


Appendix Table 1. Estimation Results without Family Fixed Effects

Panel D. Fund Alphas

\begin{tabular}{|c|c|c|c|}
\hline & \multicolumn{3}{|c|}{ Fund Alphas } \\
\hline & $(\mathrm{I})$ & (II) & (III) \\
\hline \multirow[t]{2}{*}{ Unitary Board } & -0.0711 & & \\
\hline & $(0.229)$ & & \\
\hline \multirow[t]{2}{*}{ Director Overlap (Fund) } & & 0.300 & \\
\hline & & $(0.395)$ & \\
\hline \multirow[t]{2}{*}{ Director Overlap (Family) } & & & 0.319 \\
\hline & & & $(0.377)$ \\
\hline \multirow[t]{2}{*}{ Fund Age } & 0.122 & 0.130 & 0.132 \\
\hline & $(0.0936)$ & $(0.0926)$ & $(0.0930)$ \\
\hline \multirow[t]{2}{*}{ Fund Size $_{-1}$} & $0.104^{* * *}$ & $0.103 * * *$ & $0.103 * * *$ \\
\hline & $(0.0225)$ & $(0.0225)$ & $(0.0225)$ \\
\hline \multirow[t]{2}{*}{ Family Size $_{-1}$} & $0.118^{* *}$ & $0.135 * * *$ & $0.136 * * *$ \\
\hline & $(0.0517)$ & $(0.0432)$ & $(0.0430)$ \\
\hline \multirow[t]{2}{*}{ Board Size } & -0.108 & -0.206 & -0.215 \\
\hline & $(0.453)$ & $(0.480)$ & $(0.483)$ \\
\hline \multirow[t]{2}{*}{ CEO is the Chairman } & $0.564^{* * *}$ & $0.551^{* * *}$ & $0.549 * * *$ \\
\hline & $(0.176)$ & $(0.196)$ & $(0.195)$ \\
\hline \multirow[t]{2}{*}{ Board Independence } & -0.781 & -0.503 & -0.494 \\
\hline & $(1.233)$ & $(1.235)$ & $(1.230)$ \\
\hline \multirow[t]{2}{*}{ Constant } & $4.917^{* * *}$ & $4.453^{* * *}$ & $4.444^{* * *}$ \\
\hline & $(1.524)$ & $(1.444)$ & $(1.423)$ \\
\hline Year Fixed Effects & Yes & Yes & Yes \\
\hline Style Fixed Effects & Yes & Yes & Yes \\
\hline Family Fixed Effects & No & No & No \\
\hline r2_a & 0.444 & 0.444 & 0.444 \\
\hline $\mathrm{N}$ & 39405 & 39405 & 39405 \\
\hline
\end{tabular}

